\title{
PEMANFAATAN KEGIATAN MENULIS JURNAL SEBAGAI BAHAN PENILAIAN AUTENTIK DALAM MENINGKATKAN HASIL BELAJAR SISWA PADA MATA PELAJARAN BAHASA INDONESIA KELAS XII TAHUN PELAJARAN 2017/2018
}

\author{
Mike \\ mikektb03@gmail.com
}

\begin{abstract}
SMA Negeri 3 Kotabumi
Abstract: Writing is a process of capturing what is in your thoughts and feelings. Problems in writing skills in schools are the way of assessment and curriculum achievement targets which are only measured based on the results of written tests. The subjects in this research were the process of teaching and learning activities between students and teachers/ researchers of Class XII MIPA 1 of SMAN 3 Kotabumi, North Lampung Regency in the Academic Year of 2017/2018, amounting to 34 students. After conducting research and analyzing research data, the researchers concluded that the use of journal writing skills as an authentic assessment material in Indonesian Language Subjects Class XII MIPA 1 SMA Negeri 3 Kotabumi can improve student learning outcomes. This is evidenced by the increase in the percentage of Minimum Completeness Criteria that have been determined from the first cycle to the second cycle of $23.69 \%$.
\end{abstract}

Keyword: Journal Writing, Authentic Assessment, Learning Outcomes

Abstrak: Menulis merupakan proses menungkan hal yang ada dipikiran dan perasaan. Permasalahan dalam keterampilan menulis di sekolah adalah cara penilaian dan target pencapaian kurikulum yang hanya diukur berdasarkan hasil tes-tes tertulis. Subyek dalam penelitian ini berupa proses terjadinya kegiatan belajar mengajar antara siswa dengan guru/peneliti Kelas XII MIPA 1 SMAN 3 Kotabumi Kabupaten Lampung Utara Tahun Pelajaran 2017/2018 yang berjumlah 34 Siswa. Setelah melakukan penelitian dan menganalisis data hasil penelitian, peneliti mengambil kesimpulan bahwa penggunaan keterampilan menulis jurnal sebagai bahan penilaian autentik pada Mata Pelajaran Bahasa Indonesia Kelas XII MIPA 1 SMA Negeri 3 Kotabumi dapat meningkatkan hasil belajar siswa. Hal ini dibuktikan dengan adanya peningkatan presentase Kriteria Ketuntasan Minimal yang telah ditentukan dari siklus pertama ke siklus kedua sebesar 23,69\%.

Kata Kunci: Menulis Jurnal, Penilaian Autentik, Hasil Belajar

\section{PENDAHULUAN}

Tujuan dalam pembelajaran bahasa Indonesia bagi siswa adalah meningkatkan kemampuan pemakaian bahasa Indonesia. Disamping itu, tujuan umum pembelajaran Bahasa mempunyai fungsi penting dalam perkembangan IQ, EQ, dan sosial. Melalui pendidikan Bahasa memungkinkan untuk manusia saling berbagi pengalaman, ber- komunikasi, belajar, serta meningkatkan kemampuan kesusasteraan dan intelektual. Pembelajaran bahasa Indonesia di sekolah ditujukan untuk dapat mendukung siswa mengenal dirinya, budaya, mengemukakan perasaan dan gagasan, bersosialisasi dalam masyarakat dan menemukan serta menggunakan kemampuan imajinatif dan analitis yang ada dalam dirinya. 
Berdasarkan pengamatan dan pengalaman di kelas, disimpulkan bahwa menulis selalu menjadi kurang mendapat respon dan kurang diminati yang baik dari siswa. Siswa mengalami kesulitan ketika harus menulis. Siswa sulit menemukan awal kalimat untuk menulis. Siswa kerap tidak memiliki ide yang ingin dikemukaan. pembelajaran menulis seharusnya terintegrasi dalam pembelajaran berbahasa yang lain.

Siswa kadang mengalami kebingungan dalam pembelajaran menulis karena dalam materi jenis tulisan paragraf terdapat pemilahan-pemilahan yang kaku, seperti narasi, deskripsi, argumentasi, dan eksposisi. Pengelompokan ini membuat siswa menulis terlalu kekhawatiran tidak sesuai dan salah. Padahal, kreativitas siswa untuk menulis akan mati akibat ketakutan untuk berbuat salah tersebut.

Permasalahan yang muncul berhubungan dengan pembelajaran menulis adalah capaian target kurikulum pembelajaran dan sistem penilaian yang selalu dinilair berdasarkan hasil tes tertulis saja. Padahal, keterampulan berbahasa tidak selalu dinilai menggunakan tes tertulis. Dalam mengetahui perkembangan dan kemampuan keterampilan berbahasa, salah satunya menulis tidak hanya disimpulkan dari hasil tes tertulis. Tes tertulis merupakan bagian saja dari aspek penilaian.
Menyikap hal ini perlu penerapan model penilaian menulis yang komprehensif dan autentik. Model ini melihat keberhasilan dan perkembangan kemampuan berbahasa siswa secara berkelanjutan. Proses penilaian ini dilakukan secara autentik, yang didasarkan data-data autentik dan proses perkembangan serta menggambarkan kemampuan berbahasa yang dikuasainya.

Dari hal-hal di atas, permasalahan dalam penelitian ini diurai sebagai berikut.

1. Dari studi awal yang dilakukan di sekolah terlihat rendahnya kemampuan menulis siswa.

2. Pembelajaran menulis masih dikerjakan dengan cara teoretis, dan kurang beragam.

3. Siswa tidak dilatih dan dibiasakan menulis secara terus menerus.

4. Penilaian kemampuan menulis dilakukan melalui soal-soal tes.

Tujuan penelitian untuk mengetahui apakah untuk meningkatkan hasil belajar mata pelajaran Bahasa Indonesia kelas XII tahun pelajaran 2017/2018 dapat dilakukan dengan memanfaatan bahan penilaian autentik berupa kegiatan menulis jurnal. Alternatif yang bisa diterapkan pada siswa untuk melatihkan dan membiasakan keterampilan menulis, khususnva menulis surat lamaran yaitu dengan menulis buku harian atau jurnal. Rutinitas dan pem- 
biasaan menulis sejatinya akan berubah menjadi kebiasaan perilaku yang positif. Menulis jurnal dapat menjadi sarana yang lebih menyenangkan dan berhasil membantu siswa untuk belajar menulis (Eanes, 1997).

Pembelajaran bahasa hanya fokus pada kegiatan menulis jurnal tersebut juga bisa disisipkan sehingga tidak hanya dilakukan ketika pmbelajaran menulis, Guru dapat menyediakan waktu bagi siswa untuk menuillis jurnal pribadinva $10-15$ mnt. Manfaat bagi perkembangan kemampuan menulis siswa dapat diperoleh dari kegiatan menulis jurnal yang dilakukan rutin. Secara berkelanjutan siswa akan terlatih mengemukakan perasaan dan gagasannva dengan pilihan kalimat dan kata, pola pengernbangan, dan struktur penyajian yang baik. Karena, untuk terampil menulis, siswa dibiasakan dan bebas menulis agar siswa terampil dalam menggunakan struktur dan tata bahasa secara benar ( Leonhardt, 2001).

\section{METODE}

Subyek dalam penelitian ini siswa Kelas XII MIPA 1 SMA Negeri 3 Kotabumi Kabupaten Lampung Utara Tahun Pelajaran 2017/2018 yang berjumlah 34 Siswa. Sumber data dalam penelitian ini didapatkan dari proses kegiatan belajar mengajar antara guru/peneliti dengan siswa Kelas XII MIPA 1 SMA Negeri 3 Kota- bumi Kabupaten Lampung Utara Semester Genap Tahun Pelajaran 2017/2018.

Proses pengumpulan data dalam penelitian ini digunakan metode sebagai berikut :

\section{a. Observasi / Pengamatan}

Observasi adalah Penggunaan panca indra untuk memperoleh data (informasi) yang dilakukan secara sistematis. Sementara "Melengkapidengan format atau blangko pengamatan sebagai instrument nerupakan cara yang paling efektif dalam menggunakan metode observasi"(Arikunto, 1999:234). Penelitian ini menggunakan pengamatan langsung, yaitu menggunakan bantuan sesama guru, teman sejawat, sebagai observer dalam kegiatan belajar-mengajar dan mengisi informasi yang diperoleh pada lembar format obser-vasi yang disediakan.

\section{b. Tes}

Hasil belajar merupakan poin pusat dari kegiatan belajar mengajar di sekolah, untuk mengetahui tingkat keberhasilan siswa mentransfer ilmu yang dipelajari dengan melihat prestasi belajar, sebaliknya bagi guru dapat memanfaatkannya sebagai umpan balik (feedback) untuk upaya memperbaiki strategi belajar mengajar berikutnya. Pengukuran tingkat keberhasilan be- 
lajar siswa umumnya menggunakan tes.

Untuk mengukur sejauh mana manfaat kegiatan menulis jurnal dalam penilaian autentik mampu meningkatkan aktivitas belajar yang tercermin dalam penguasaan materi yang diajarkan, pada akhir kegiatan peneliti mengadakan tes. Tes yang digunakan adalah tes rancangan guru dengan proses uji berkali-kali sehingga tidak diketahui ciri-ciri dan kebaikannya" Arikunto, 1999).

Proses analisis data hasil kegiatan guru dan aktivitas siswa, peneliti mengambil langkah-langkah sebagai berikut.

1. Menentukan tingkat kemampuan guru memimpin diskusi kelompok.

2. Menghitung aktivitas siswa masingmasing aspek aktivitas maupun aktivitas masng-masing siswa.

3. Menentukan pada bagian mana komponen keterampilan guru memimpin diskusi dan aktivitas siswa yang perlu diperbaiki.

4. Mengadakan penilaian untuk menentukan perubahan tindakan yang dilakukan dapat berpengaruh terhadap hasil belajar siswa.

Proses Analisis data dari hasil test siswa dilakukan kegiatan sebagai berikut.

1. Menentukan jumlah skor jawaban benar hasil tes siswa.
2. Menentukan nilai siswa

Dari data test Pilihan Ganda ditentukan nilai dengan menggunakan rumus berikut.

Skore $=\frac{\text { Jumlah yang benar }}{\text { Jumlah Soal }} \times 100 \%$

3. Memasukkan hasil perhitungan skore ke dalam tabel analisis uji blok pada setiap siklus.

4. Menghitung jumlah siswa dengan nilai mencapai Kriteria Ketuntasan Minimal (KKM).

5. Menyusun nilai ke dalam tabel distrebusi frequensi sebagai berikut.

Tabel 1

Distribusi Frekuensi Hasil Uji Blok Siswa

\begin{tabular}{|c|c|c|c|}
\hline \multirow{2}{*}{$\begin{array}{c}\text { Interval } \\
\text { Nilai }\end{array}$} & $\begin{array}{c}\text { Jumlah } \\
\text { Siswa }\end{array}$ & $\begin{array}{c}\text { Dalam } \\
\mathbf{\%}\end{array}$ & \multirow{2}{*}{ Ketuntasan } \\
\hline $90-100$ & & & $\mathrm{~T}$ \\
\hline $80-89$ & & & $\mathrm{~T}$ \\
\hline $70-79$ & & & $\mathrm{~T}$ \\
\hline $60-69$ & & & TT \\
\hline $0-59$ & & & TT \\
\hline Jumlah & & & \\
\hline
\end{tabular}

6. Menampilkan perkembangan peningkatan kemampuan guru memimpin diskusi, peningkatan aktivitas dan prestasi belajar siswa masing-masing dalam sebuah table.

7. Menampilkan perkembangan peningkatan keterampilan guru memimpin diskusi, peningkatan aktivitas siswa dan prestasi belajar siswa masingmasing dalam sebuah grafik batang. 
8. Kegiatan menginterprestasikan hasil analisis data adalah upaya untuk memberikan makna terhadap angkaangka (dalam penelitian kuantitatif) ataupun kumpulan pernyataan (dalam penelitian kualitatif) setelah proses analisis data yang terkumpul. Yang dimaksud dengan interprestasi data dalam arti sempit ialah peneliti memberikan penjelasan terbatas hanya pada hasil analisis data saja tanpa menghubungkannya dengan hasil penelitian ataupun teori lain yang relevan.

9. Berdasarkan perhitungan dan analisis data pada Siklus I dan Siklus II, maka penelitian tindakan kelas berhasil bila Pencapaian KKM siswa berdasarkan hasil tes pada Siklus II lebih baik dari Siklus I. Jika syarat-syarat di atas dapat dipenuhi, berarti penggunaan kegiatan menulis jurnal sebagai bahan penilaian autentik dapat meningkatkan aktivitas dan hasil belajar siswa.

\section{HASIL DAN PEMBAHASAN}

\section{Hasil}

\section{a. Perencanaan Tindakan}

Kegiatan menulis jurnal di dalam penelitian ini menjadi penunjang yang tersisipkan dalam pembeiajaran inti berdasarkan perencanaan yang telah disusun untuk kegiatan pembelajaran dilakukan 3 siklus. Pelaksanaan ditiap siklusnya tersusun pada (1) pemahaman dan pemodelan. (2) Membiasaan menulis jurnal, dan (3) pelaksanaan evaluasi yang autentik jurnal.

\section{b. Pelaksanaan Tindakan}

Penelitian tersusun dalam 3 siklus. Di tiap siklus terdapat tiga pokok pembelajaran yaitu (1) pemahaman materi dan percontohan kegiatan menulis jurnal, (2) pembiasan menulis jurnal, dan (3) penilaian autentik yang memanfaatkan jurnal siswa. Setiap siklus tersusun dari perencanaan, pengamatan, analisis temuan, dan refleksi .

\section{Pemahaman materi dan Percontohan Kegiatan Menulis}

Langkah pembelajaran yang terdapat pada kegiatan pemahaman konsep dan permodelan:

(1) Penyampaikan tujuan.

(2) menumbuhkan skemata.

(3) mendiskusikan cara menulis surat lamaran yang baik,

(4) latihan penulisan surat lamaran yang baik,

(5) mengintegrasikan menulis surat lamaran dengan jurnal,

(6) diskusi cara menulis jurnal.

(7) menunjukkan contoh jurnal

(8) menulis jurnal sebagai tahap awal untuk pengamatan. 
Bersama kegiatan-kegiatan itu siswa membangun konsep pengetahuan tentang menulis surat lamaran yang baik.

\section{Pembiasaan Menulis Jurnal}

Siklus pertama kegiatan yang dilaksanakan ada 6 langkah pokok berupa:

1. Penyediakan waktu untuk menulis,

2. Memerintahkan siswa menulis gagasan,

3. Merangsang munculnya ide siswa,

4. Monitoring.

5. memberi motivasi,

6. mengumpulkan jurnal untuk dikoreksi.

Langkah-langkah pembelajaran di siklus II tetap sama, ada sedikit variasi dibanding pembelajaran pada siklus I. Diawali siswa diminta untuk menulis kegiatan kesehariannya, pengalaman perasaan, tanggapan, atau gagasannya tentang sesuatu. Pertemuan berikutnya, siswa dipancing mengeluarkan gagasan menulis melalui kegiatan tanya-jawab.

Langkah-langkah pembelajaran di siklus ini juga diperbaiki kembali sesuai hasil refleksi siklus II. Dalam tiap siklus, pembiasaan dan pelaksanaan menulis jurnal dilaksanakan 4 kali. Pada dua kali pertemuan menulis jurnal dibarengi dengan evaluasi. Respon rnembuat siswa senang karena guru menunjukkan simpati dan menanggapi terhadap persoalan yang dialaminya. Ini memacu motivasi terus menulis. Siswa berasumsi karyanya dibaca dan dihargai oleh guru mereka.

\section{Penilaian Autentik Memanfaatkan Tulisan dalam Jurnal Siswa}

Penilaian autentik dilakukan dalam tiap siklus. Penilaian yang dilakukan guru meliputi penilaian hasil dan penilaian proses yang dilaksanakan secara berkesinambungan. Penilaian oleh siswa melingkupi penilaian tulisan yang dihasilkan oleh diri sendiri dan antarsiswa. Dilakukan dua kali penilaian, penilaian diri sendiri diadakan usai kegiatan metulis ke 1 dan 2. Berikutnya berupa evaluasi antarteman dilakukan pada kegiatan menulis ke 3 dan 4. Siswa penilai mengoreksi dan mencermati kesalahankesalahan tersebut.

Laporan tentang perkembangan menulis siswa, khususnva menulis surat lamaran menjadi hasil penilaian autentik. Data perkembangan kemampuan siswa selama mendapat tindakan diperoleh dari pencatatan dan analisis hasil tulisan setiap pertemuan. Hasil penilaian itu selanjutnva menjadi bahan perencanaan pembelajaran berikutnya.

Melalui pembiasaan menulis siswa terbiasa menulis surat lamaran dan kemampuan pun meningkat, hal ini dapat dilihat pada hasil penelitaan tindakan ini. Hal ini menunjukkan bahwa dengan 
peningkatan awal terlihat dari gagasan dan pilihan topik. Jumlah yang ditulis semakin bertambah banyak dan menunjukkan hal yang beragam. Peningkatan terjadi pada tiap siklus tindakan. lebih jelas dapat terlihat pada Tabel 4 berikut :

Tabel 2

Perbandingan Persentase Ketuntasan Siswa Setiap siklus

\begin{tabular}{|c|c|}
\hline SIKLUS I & SIKLUS II \\
\hline $63,15 \%$ & $86,84 \%$ \\
\hline
\end{tabular}

\section{Pembahasan}

Dari tabel siklus I kualitas siswa ratarata berkualitas cukup dan siklus II meningkat berubah menjadi baik. Dengan kata lain, Kesalahan tata bahasa dalam tulisan masih ditemukan, tetapi berkurang dan tidak sampai menghilangkan makna dari gagasan Siswa mudah menulis di kelas disebabkan siswa telah memiliki coretan yang dibuat di rumah. Siswa juga terpacu untuk menulis karena tidak terbeban tugas yang berat Keantusiasan, semangat, dan motivasi menulis semakin meningkat. Hal itu ditunjukkan dengan membuat coretan tulisannya di rumah tanpa ditugaskan.

Peningkatan diperolah karena bimbingan yang diberikan secara terus menerus dan tidak terjadwal. Sekalipun menulis jurnal bersifat informal tetapi sehingga dapat menggali ide-ide kreatif siswa dalam menentukan gagasan. Pada pembiasaan menulis jurnal, siswa lebih memerlukan waktu untuk menghasilkan tulisan, namun seiring waktu memampuan menulis menjadi semakin terampil. Dalam prosesnya siswa membuat coretan tulisannya, walaupun guru tidak menugaskan.

Terdapat 4 indikator peningkatan kemampuan menulis surat lamaran yang muncul dari penilaian autentik yang dilakukan siswa.

1. Mampu menemukan kesalahan ejaan dan tanda baca,

2. Mampu menemukan kalimat yang tidak sesuai dalam paragraph

3. Mampu mengoreksi dan memperbaiki struktur kalimat yang salah

4. Mampu menemukan dan memperbaiki diksi yang tidak tepat

Penilaian autentik memotivasi siswa untuk membangun pengetahuannya sendiri tentang aturan tata cara penulisan yang benar. Selain itu, Penilaian autentik oleh guru mempengaruhi peningkatan kemampuan menulis surat lamaran karena Guru menghimpun informasi dari aktivitas siswa saat menulis dan menemukan kesalahan yang sering dilakukan siswa dalam tulisannya. Guru menilai dengan mendokumentasikan kualitas perkembangan tulisan secara berkelanjutan, hasil dokumentasi itu berupa gambaran rinci peningkatan kemampuan menulis surat lamaran siswa. 


\section{SIMPULAN}

Setelah selesai melakukan dan menganalisis data hasil penelitian, maka dapat disimpulkan bahwa hasil belajar siswa meningkatkan melalui kegiatan menulis jurnal sebagai bahan penilaian autentik Mata Pelajaran Bahasa Indonesia Kelas XII MIPA 1 SMAN 3 Kotabumi. Hal ini dibuktikan dengan adanya peningkatan presentase Kriteria Ketuntasan Minimal yang telah ditentukan dari siklus pertama ke siklus kedua sebesar 23,69\%.

\section{DAFTAR RUJUKAN}

Capacchione. L. (1989). The Creative Journal For Children: A Guide for, Teacher Parents, and Counselors. Boston: Shambala.

Depdikbud. (1998). Penelitian Tindakan Kelas. Bahan Pelatihan Jakarta: Dikdasmen Depdikbud.

Eanes, R. (1997). Literacy Content Area: Teaching Today's and Tomorrow. New York: Delmar Publisher.

Federikson, J. \&, A Collins. (2002). What is Authentic Assesment: Condition of Use Term. Hougton Mifflin Company (online),

Hammond, L.D. dan J Snyde,.D.(2001). Authentic Assesment of Reaching Indonesia Context, U.S. Departemen Education (online), (http:www.Contextual.org/abs2)

Laonhardt, M.(2000). 99 Cara Menjadikan Anak Bergairah Menulis. Terjemahan oleh Eva Y. Nukman. 2001. Bandung Kaifa. 